The research program of the Center for Economic Studies (CES) produces a wide range of theoretical and empirical economic analyses that serve to improve the statistical programs of the U.S. Bureau of the Census. Many of these analyses take the form of CES research papers. The papers are intended to make the results of CES research available to economists and other interested parties in order to encourage discussion and obtain suggestions for revision before publication. The papers are unofficial and have not undergone the review accorded official Census Bureau publications. The opinions and conclusions expressed in the papers are those of the authors and do not necessarily represent those of the U.S. Bureau of the Census. Republication in whole or part must be cleared with the authors.

\title{
MERGERS AND ACQUISITIONS, EMPLOYMENT, WAGES AND PLANT CLOSURES IN THE U.S. MEAT PRODUCT INDUSTRIES:
}

EVIDENCE FROM MICRO DATA

by

Sang V. Nguyen *

U.S. Bureau of the Census

and

Michael Ollinger *

U.S. Department of Agriculture

CES 07-08 March, 2007

All papers are screened to ensure that they do not disclose confidential information. Persons who wish to obtain a copy of the paper, submit comments about the paper, or obtain general information about the series should contact sang V. Nguyen, Editor, Discussion Papers, Center for Economic Studies, Washington Plaza II, Room 206, Bureau of the Census, Washington, DC 20233-6300, (301-763-1882) or INTERNET address sang.v.nquyen@Census.gov. 


\begin{abstract}
The purpose of this paper is to evaluate the impact of mergers and acquisitions (M\&As) on wages and employment and plant closures in the meat packing, prepared meat products, and poultry slaughter and processing industries over 1977-87 and 1982-92. The analysis relies on a balanced panel dataset of all plants owned by meat and poultry firms that existed over 1977-87 or 1982-92. We find that (1) M\&As are positively associated with wages in the meat packing and prepared meat products industries over 1977-87, but not over 1982-92; (2) changes in employment are positively related to M\&As in all three meat and poultry industries over 1977-87, but only in the poultry industry over 1982-92; and (3) M\&As are negatively associated with plant closures.
\end{abstract}

Econlit Subject Code: J630

Key words: mergers and acquisitions, wages, employment, meat industry, poultry industry,

* This paper reports the results of research and analysis undertaken by the authors. It has undergone a more limited review than official publications. The paper has been screened to insure that no confidential data are revealed. The judgments and conclusions herein are those of the authors and do not necessarily reflect those of the U.S. Bureau of the Census or U.S. Department of Agriculture. The authors are responsible for any remaining errors. 


\section{INTRODUCTION}

The consolidation of the U.S. meat products industry, including a wave of mergers, over the past two decades has coincided with a substantial drop in real wages in large plants and an increase in concentration levels (MacDonald, et al, 1999). For example, as four firm concentration ratios in steers and heifers more than doubled to $81 \%$ over $1980-97$, wages dropped from about $\$ 10.00$ to $\$ 8.50$ per hour in plants with more than 500 employees (MacDonald, et al,1999).

Do mergers and acquisitions (M\&A) account for a disproportionate number of plant closings, job losses, and wages reductions? MacDonald et al. (1999) point out that the early 1980s was a time of substantial industry consolidation and stagnant or declining wages, and Ollinger et al. (2005) show that mergers and acquisitions rose sharply over two census periods -1977-82 and 1982-87 -- and then dropped. However, McGuckin and Nguyen (1998) found that acquiring food industry firms raised wages of employees of acquired plants by 12 percent and employment by 16 percent over 1977-82. Earlier, Brown and Medoff (1988) determined that, except for divestitures, M\&As had little effect on employment and wages in a sample of mostly small firms in the state of Michigan.

Then, Lichtenberg and Seigel (1992a) found that M\&As of manufacturing plants led to reductions in both employment and wages at central offices but had little effect at production establishments. More recently, McGuckin and Nguyen (2001) found that M\&As positively affected labor productivity, wages and employment growth at acquired plants and that plants 
changing owners were more likely to survive than those that did not change owners.

These studies provide valuable insights into the impact of M\&As on the labor market. However, they either used data for the entire U.S. manufacturing sector (Lichtenberg and Siegel, 1992b), or for a single state (Brown and Medoff, 1988), or for a broadly defined industry (McGuckin and Nguyen, 2001). Thus, these results may not hold for specific, narrowly defined industries.

The purpose of this paper is to evaluate the impact of mergers and acquisitions on wages and employment of acquired plants owned by meat packing plants (SIC 2011), prepared meat products plants (SIC 2013), and poultry slaughtering and processing (SIC 2015) over the 197787 and 1982-92 periods. The analysis relies on a balanced panel dataset of all plants owned by meat and poultry firms that existed over 1977-87 or 1982-92 and uses a two stage least squares model in $\log$ form to regress wage and then employment growth on an instrumental variable for ownership change, a dummy variable for plants owned by acquiring firms, beginning of the period plant employment and production worker plus other worker wages, and several dummy and control variables. The control group consists of non-acquired plants owned by nonacquiring firms. We use an instrumental variable for acquisitions to control for sample selection bias since buying firms may only acquire plants with high growth potential (Nguyen and Ollinger, 2006). Since acquiring plants may also reduce employment and wages by closing plants, we used a probit model to estimate the effect of plant acquisitions on plant closures.

Our empirical model is similar to that by McGuckin and Nguyen (2001), but differs in two important ways. First, McGuckin and Nguyen's study was based on data for the food and kindred product industry (SIC 20), a broadly defined industry yielding results that may not apply to the specific meat and poultry industries. Second, while McGuckin and Nguyen's (2001) study 
covered only M\&As occurring over the 1977-82, our work considers two major merger periods: 1977-1982 and 1982-1987 and evaluates the performance of acquired plants over ten year periods ending in 1987 and 1992.

Results indicate that M\&As positively affected changes in wages in the meat packing and prepared meat products industries over 1977-87 but not during 1982-92 and positively affected changes in employment in all three meat and poultry industries over the 1977-87 period but only poultry for 1982-92. In no case does M\&A adversely affect changes in either employment or wages. Initial wage costs and plant size do have negative effects on wage changes and employment, however, suggesting that high wage plants had slower wage growth than smaller plants. Our results also show that M\&A negatively affects the likelihood of plant closure and that high wages relative to variable costs encourage plant shutdowns.

\section{EMPIRICAL MODELS}

The effects of mergers on workers are not obvious. M\&As such as hostile takeovers are infamous because of publicity associated with the wholesale changes that sometimes accompany them: managements dismissed, plants closed, pension benefits abrogated, and wages reduced. But, M\&As need not be associated with downsizing and plant closure. New ownership can bring new capital, marketing outlets, and expertise to a firm, leading to growing sales, job creation, and rising wages. Ownership change can also lead to changes in the distributions of high and low skilled jobs, the mixture of rents going to labor and owners, and the amount of economic rents accruing to firms. In the face of these differences, we turn to empirical analysis. 


\subsection{The Wage and Employment Equations}

The effect of mergers and acquisitions on employment and employee wages has been a contentious issue in the meat and other industries. Following previous studies (e.g., McGuckin, Nguyen and Reznek, 1997 and McGuckin and Nguyen, 2001), we specify the following empirical model that relates M\&As to changes in plant employment (EMP) and wages (WAGE). The employment equation can be written as:

(1) $\operatorname{lnEMP} P_{t}-\ln E M P_{t-1}=a o+a_{1} \operatorname{Pr}(A C)+a_{2} B U Y E R \_P L A N T+a_{3} \operatorname{LnWAGE_{t-1}}$

$$
\begin{aligned}
& +a_{4} \operatorname{LnEMP_{t-1}}+a_{5} \operatorname{Ln}(N P W / P W)+a_{6} \operatorname{Ln}(\mathrm{K} / \mathrm{S}) \\
& +a_{7} \operatorname{Ln}\left(S P_{-} R A T I O\right)+a_{8} A G E 72+a_{9} A G E 77 \\
& +a_{10} M U L T I+a_{11} O T_{-} M E A T+a_{12} N O T_{-} F O O D+ \\
& +a_{13} M U L T I^{*} L n E M P_{t-1}+a_{14} O T_{-} M E A T^{*} \operatorname{LEM} E P_{t-1} \\
& +a_{15} N O T \_F O O D^{*} \operatorname{LnEMP} P_{t-1}+\mathrm{e}
\end{aligned}
$$

and similarly for wages:

(2) $L n W A G E_{t}-\ln W A G E_{t-1}=a o+a_{1} \operatorname{Pr}(A C)+a_{2} B U Y E R \_P L A N T+a_{3} \operatorname{LnWAGE_{t-1}}$

$$
\begin{aligned}
& +a_{4} \operatorname{LnEMP} P_{t-1}+a_{5} \operatorname{Ln}(N P W W / P W W)+a_{6} \operatorname{Ln}(K / S) \\
& +a_{7} \operatorname{Ln}\left(S P \_R A T I O\right)+a_{8} A G E 72+a_{9} A G E 77 \\
& +a_{10} M U L T I+a_{11} O T \_M E A T+a_{12} N O T \_F O O D+ \\
& +a_{13} M U L T I^{*} \operatorname{LnEMP}_{t-1}+a_{14} O T_{-} M E A T^{*} \operatorname{LnEMP} P_{t-1} \\
& +a_{1.5} N O T \_F O O D^{*} \operatorname{LnEMP} P_{t-1}+e
\end{aligned}
$$

where $\mathrm{Ln}$ is natural logarithm, $E M P_{t}$ and $W A G E_{t}$ are employment and wages at the end of the two study periods (1987 and 1992) and $E M P_{t-1}$ and $W A G E_{t-1}$ are employment and wages at the 
beginning of the study periods (1977 and 1982). The variable $\operatorname{Pr}(A C)$ is an instrumental variable representing the probability of the plant being acquired and is estimated using equation (3) below. BUYER_PLANT equals one if the plant is initially owned by the acquiring firm in 1977 or 1982 and operated by the acquiring firm through 1987 or 1992 and it equals zero otherwise. The omitted category is the plants of non-acquiring firms. There are several other control variables: $\triangle N P W / P W$ is the change in the ratio of non-production workers to production workers in the employment equation; its counterpart in the wage equation $(\triangle N P W W / P W W)$ is the change in the ratio of non-production worker wages $(N P W W)$ to production worker wages $(P W W)$; $\Delta(K / S)$ is the change in the capital to sales (output) ratio; $\triangle S P_{-} R A T I O$ equals the change in the product specialization ratio, i.e., the share of a plant's output coming from 5-digit Census SIC code products such as cattle slaughter or poultry slaughter products. $A G E 72$ equals one for plants that existed before 1973, AGE77 is one for plants were open from 1973 to 1977, MULTI equals one for plants owned by a multi-unit firm; all three variables are zero otherwise. $O T \_M E A T$ equals one if the plant is a non-meat plant and zero otherwise, NOT_FOOD equals one if the plant is a non-food plant and zero otherwise, and e is the error term. The model also

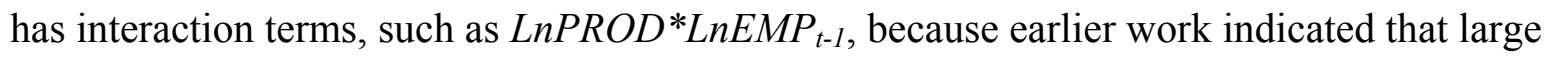
firms (or plants) behave differently from small ones (McGuckin and Nguyen, 1995 \& 2001, and Nguyen and Ollinger, 2006).

The above wage and employment equations are similar to those used in McGuckin, Nguyen, and Reznek (1997), Brown and Medoff (1988), and Lichtenberg and Siegel (1992b) who examined the impact of M\&As on worker wages. They also follow specifications used by Block (1979), Ashenfelter and Kruger (1994), and other researchers analyzing the effect of training on workers' earnings and employment. 
The independent variables have been found to be important in a variety of studies of wages and employment. Brown and Medoff (1989) and Dunne and Roberts (1990) determined that employers' size $(E M P)$ and age $(A G E)$ had significant impacts on wages. Dunne and Roberts (1990) found that the capital labor ratio, 2-digit SIC code industry, and geographic region affect wages.

The models also control for initial worker wages $\left(W A G E_{t-1}\right)$, unique plant characteristics, and changes in worker skill level $\Delta(N P W / P W)$ and plant specialization $\left(\triangle S P \_R A T I O\right)$. Economic theory suggests that high initial wages should discourage hiring more workers and wage growth. Following Ashenfelter and Kruger (1994), we also account for differences in worker skill levels with a variable defined as the first difference of the ratio of number (wages) of non-production workers (wages) to production workers (wages). We control for changes in the specialization ratio ( $\left.\triangle S P \_R A T I O\right)$ because MacDonald et al (1999) and Ollinger et al (2000) found that plants shifted dramatically toward a greater specialized output mix over 1967-92. The remaining variables control for firm and industry effects.

\subsection{Endogenous M\&A}

Recent studies (Nguyen and Ollinger, 2006; McGuckin and Nguyen, 1995; Lichtenberg and Seigel, 1992a; Baldwin, 1991) suggest that M\&A and plant productivity growth were positively correlated throughout the 1980s merger wave. This positive relationship implies the existence of sample selection bias in which highly productive plants are more likely to be acquired.

Accordingly, we specify a selection equation that predicts ownership changes (equation 3 ) in 
which predicted ownership change serves as an instrumental variable in the employment and wage regressions.

Predicted ownership change equals the fitted value of AC (ACHAT) and is obtained from the relationship $\operatorname{Pr}(\mathrm{AC})=\mathrm{q}(-\mathrm{ACHAT})$ in which $\mathrm{q}$ is the cumulative density function for the standard normal variable. The independent variables determining ownership change follow from previous research (Nguyen and Ollinger, 2006; McGuckin and Nguyen, 1995; Lichtenberg and Seigel, 1992a) that found that the probability of a firm being acquired is a function of its premerger performance and other characteristics.

$$
\begin{aligned}
& A C_{t, t+1}=b_{0}+b_{1} \operatorname{LnPROD}_{t}+a_{2} \operatorname{LnEMP}_{t}+a_{3} \operatorname{LnSP}_{-} R A T I O_{t} \\
& +a_{4} O T_{-} M E A T+a_{5} N O T \_F O O D+a_{6} L n P R O D_{t^{*}} L n E M P_{t} \\
& +a_{7} L n P R O D_{t} * L n S P \_R A T I O_{t}+a_{8} L n P R O D^{*} O T_{-} M E A T_{t} \\
& +a_{8} \operatorname{LnPROD}_{t^{*}} N O T_{-} \mathrm{FOOD}_{t}+u_{i}
\end{aligned}
$$

where $A C_{t, t+1}$ equals one if the plant was acquired during the period $\mathrm{t}, \mathrm{t}+1$ and zero otherwise. $P R O D_{t}$ is a measure of a plant's pre-merger performance (productivity) and is defined as the plant's labor productivity (total value of shipments divided by number of employees) divided by industry average labor productivity. $E M P_{t}$, a measure of plant size, $S P \_R A T I O$, and the two dummy variables --NOT_FOOD and $O T_{-} M E A T$ - have been defined previously. These variables follow several models of M\&As, such as Nguyen and Ollinger (2006). 


\subsection{Plant Closing Equation Equations}

The above analysis is based on surviving plants, yet an acquiring firm could buy another plant and close it, thereby decreasing employment and wages. Accordingly, we follow a standard model to specify an empirical model of plant closing (equation 4). See Caves (1998) for recent comprehensive survey of research on plant (or firm) entry, exit and survival.

$$
\begin{aligned}
& \text { (4) } P C_{t}=a_{0}+a_{1} \operatorname{Pr}(A C)+a_{2} B U Y E R \_P L A N T+a_{3} L n P R O D_{t-1}+a_{4} L n E M P_{t-1} \\
& +a_{5} \text { LnWAGE_SHARE }+a_{6} A G E 72+a_{7} A G E 77+a_{8} \text { MULTI } \\
& +a_{9} O T \_M E A T+a_{10} N O T \_F O O D+a_{11} \operatorname{Pr}(A C)^{*} \operatorname{LnEMP} P_{t-1} \\
& +a_{12} \text { BUYER_PLANT*LnEMP }{ }_{t-1}+a_{13} \operatorname{LnPROD}{ }_{t-1} * \operatorname{LnEMP}_{t-1} \\
& +a_{14} \operatorname{LnWAGE} S H A R E_{t-1} * \operatorname{LnEMP} P_{t-1}+a_{15} A G E 72 * \operatorname{LnEMP} P_{t-1} \\
& +a_{16} A G E 77 * \operatorname{LnEMP} P_{t-1}+a_{17} M U L T I^{*} \operatorname{LnEMP} P_{t-1} \\
& +a_{18} O T_{-} M E A T^{*} \operatorname{LnEMP} P_{t-1} a_{19} F O O D^{*} \operatorname{LnEMP} P_{t-1}+e_{t}
\end{aligned}
$$

where $P C_{t}$ equals 1 if the plant was closed by year $t$ and zero otherwise. Independent variables are based on previous research and most have been defined before. We use the probability of the plant being acquired, $\operatorname{Pr}(A C)$ due to potential sample selection bias. Following McGuckin and Nguyen (1998), we also control for plants owned by the acquiring firms, BUYER_PLANT. The omitted ownership group is those plants owned by non-acquiring firms. Initial plant relative productivity $\left(\operatorname{LnPROD}_{77}\right)$ is defined above and comes from McGuckin and Nguyen (1998). We include plant size, $L n E M P_{t-1}$, and plant age, $A G E 72$ and $A G E 77$, because of relationships found between these variables and plant survival by several researchers (Dunne, Roberts and Samuelson (1989), and Baldwin, 1991). WAGE_SHARE is worker compensation costs as a share of total costs and is included because MacDonald et al. (1999) document large reductions in 
labor costs over 1972-92. The other variables control for firm effects, i.e. multi-plant verses single-plant firms, and product output. Finally, we allow for non-linear effects of initial productivity and employment size on plant closure with interaction terms.

We use the Probit regression to estimate our model because is better suited than OLS when the response is discrete. See Green, 2000 for details.

\section{DATA AND VARIABLE MEASUREMENT}

\subsection{Data Source: The Longitudinal Research Database (LRD)}

The data used in this study are taken from the Census Bureau's LRD which contains information on output, employment, and costs for individual U.S. manufacturing establishments. The output data include total value of shipments and value added; employment data consist of the number of non-production workers, production workers, worker wages, and hours for production workers; cost data is comprised of information on capital, labor, energy, materials, and selected purchased services.

An important feature of the LRD is its plant classification and identification information: These include firm affiliation, location, product and industry, and various status codes which identify, among other things, birth, death, and ownership changes. These identifying codes are used in developing both the longitudinal plant linkages and ownership linkages among plants. For a more complete description of the LRD see McGuckin and Pascoe (1988). For a detailed discussion of the identification of ownership changes (through M\&As), see Nguyen, 1998. 


\subsection{Sample Coverage and Variable Measurement}

We examine three 4-digit meat and poultry industries: meat packing (SIC 2011), prepared meat products (SIC 2013), and poultry slaughter and processing (SIC 2015) over 1977-87 and 198292. The sample of plants includes all plants owned by meat and poultry firms that existed in 1977 and 1982. Wage and employment changes are evaluated for each group over ten-year periods: $1977-87$ and 1982-92. We use a ten year period because that allows changes to occur for 5 to 9 years after acquisitions, providing sufficient time for the acquiring firm to integrate acquired plants into their operations, or to dispose of them.

There are two important reasons for focusing on mergers occurring over 1977-92. First, the period includes four censuses of manufactures so that we are confident of correctly identifying all acquired plants. We only use data from census year because data are available only from a sample of plants in non-census years. Second, the period encompasses the beginning and ending years of the latest major merger movement in the meat and poultry industries.

The main variables examined in this study are employment and wages. Employment equals the total number of employees and consists of production and non-production workers. Wages are defined as workers' annual salaries. This measure of wages does not include nonwage costs because separate data on these costs are not available for the two types of workers, and Dunne and Roberts (1993) report that non-wage costs are poorly reported in Census data. Since Census wage data are nominal wages, we deflated them by the consumer price index taken from the Survey of Current Business (September, 1993). Other variables are discussed below in the context of the presentation of the empirical models. 


\subsection{MAs in the Meat Products Industry:}

Using the LRD, we identified every meat and poultry plant that was acquired over 1977-82 and 1982-87 and its buyer and seller. Next, using these firms, we identified all manufacturing plants owned by acquiring and acquired firms at the beginning of the period (1977 or 1982), whether or not they were located in the meat products industry. The sample for $1977-82$ for the meat packing, prepared meat products, and poultry slaughter and processing industries included 251, 178 and 312 plants, respectively. The corresponding numbers of all plants owned by acquiring firms in 1977 are 684, 412 and 518, respectively. These plants may or may not have been in the meat or poultry industry. We also identified the firms owning the plants in meat and poultry that were not acquired over 1977-82. These non-acquiring firms in the three industries owned 2,042, 1,214 and 442 plants in 1977, respectively. Thus the 1977-82 data consists of 6,053 plants.

The sample of plants for 1982-87 included 226, 353 and 316 plants, respectively. The acquiring firms owned 315, 580 and 560 plants; the numbers of plants owned by non-acquiring firms amounted to 1,326 by meat packing, 1,155 by prepared meat products, and 359 poultry slaughter and processing plants. In total, the 1977-82 sample consists of 5,190 plants. 


\section{EMPIRICAL RESULTS}

\subsection{The Effect of M\&A on Plants’ employment Change}

Columns (1) - (3) of Table 1 show the regression estimates of the employment growth equations for the meat packing, prepared meat products, and poultry and processing slaughter industries, respectively, for 1977-87; columns (4) - (6) present the estimates for the same industries for 1982-92. All the equations are estimated using the two-stage procedure discussed above.

\section{Table 1 goes here.}

OLS regression results show that the coefficients on the ownership change variable, $\operatorname{Pr}(A C)$, are positive and statistically significant at the one percent level for all 3 industries for 1977-87. Over 1982-92, however, only the coefficient for $\operatorname{Pr}(A C)$ for poultry is significant and positive; the coefficients for the two meat industries are negative and insignificant. Although the 1977-87 results are consistent with McGuckin and Nguyen's (2001) finding for the entire food industry, it cannot be claimed that acquisitions lead to positive employment growth because the results from the later period are ambiguous. One can say, however, that M\&As did not cause massive job dislocations, and may have led to some employment growth in some industries.

One explanation for the mixed results is that consolidation in the earlier period (1972-82) enabled some firms to combine output in some plants in order to enhance productivity in those 
facilities while closing others. Since acquired plants are likely to be better assets than the plants the firm held prior to the merger (McGuckin and Nguyen, 1995; Nguyen and Ollinger, 2006), output and employment would have grown in these plants and shrank elsewhere. In the later period (1982-92) this structural shift had pretty much played itself out, providing fewer opportunities to shift out from less productive existing plants to newly acquired more efficient ones. Thus, acquired plants tended to add employees in the first period but not the second one.

The remaining coefficients of the employment equation indicate that plant characteristics and initial conditions contribute significantly to employment changes. The coefficients for the initial size variable $\left(\ln E M P_{77}\right)$ are negative in the two meat industries over both periods and positive in poultry slaughter and processing. Coefficients for initial wages $\left(\ln W A G E_{77}\right)$ are the opposite of those for initial size. These results suggest that large meat plants grew slower than smaller ones but the reverse was true for poultry plants. On the other hand, meat plants that paid higher initial wages tended to hire workers at a faster rate than plants that paid lower initial wages and, again, the reverse was true for poultry plants.

The negative coefficients for the age variables indicate that older plants increase their employment at a slower rate than younger plants. This is consistent with previous research (Brown and Medoff, 1989; Dunne and Roberts, 1990) that found that successful (surviving) young plants grow faster than older plants. The generally negative effects of the capital intensity variable $\operatorname{Ln}(\Delta \mathrm{K} / \mathrm{S})$ are consistent with Dunne and Roberts (1990). Finally, changes in plant specialization have mixed effects on employment growth. 


\subsection{The Effect of M\&As on Plant Wages}

Table 2 presents the estimates of the wage equation. Columns (1) - (3) contain the results for 1977-87; columns (4) - (6) have the estimates for 1982-92. All the coefficients for $\operatorname{Pr}(\mathrm{AC})$ are positive but only two are significant, implying that wages increased somewhat more quickly for plants undergoing M\&A than plants that did not experience ownership changes. This result is consistent with McGuckin and Nguyen (1995) who found a significantly positive impact of acquisitions on wage growth over 1977-87.

\section{Table 2 goes here.}

Wage growth results may be due to two phenomena. Worker compensation at existing plants may have dropped because worker bargaining power in these plants diminished due to falling demand for meat products, competition from non-union plants, and the availability of low cost immigrant labor (MacDonald, et al.1999). Compensation at newly acquired plants, on the other hand, may have risen because of greater economies from newer plants and productivity growth from newly acquired plants.

The estimates for other variables are consistent with previous studies. The coefficients for initial wages $\left(W A G E_{t-i}\right)$ are negative and significant in five of six cases, indicating that high initial wages lead to slower wage growth. Additionally, plant size has a positive and age a

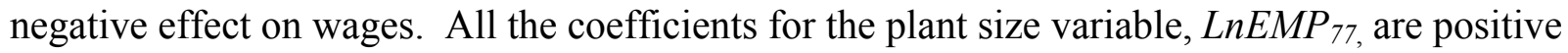


(three are significant) and those for $A G E 72$ are negative. These results indicate that younger, larger plants had greater wage growth than older, smaller plants. Also, consistent with Ashenfelter and Kruger (1994), the coefficients for the ratio of the change in non-production worker wages to production worker wages $(\triangle N P W W / P W W)$ are positive in all cases and significant in five of them. Previous work by Dunne and Roberts (1990) suggested that capital intensity has a negative effect on plant wages, but our results are mixed. The coefficient for capital intensity is significantly negative in meat packing and poultry slaughter and processing over 1977-87 and significantly positive in meat packing over 1982-92. Finally, results suggest that multi-plant meat plants (MULTI) increase wages faster than single-unit firms but that the opposite occurs in poultry.

\subsection{The Effect of M\&As on Plant Closings}

The probit regression results for 1977-82 are reported in table 3, while those for 1982-1987 are shown in table 4. In each table, columns (1), (3) and (5) show the results for the simple linear model for the meat packing, prepared meat products, and chicken slaughter and processing industries, respectively, and columns (2), (4) and (6) contain the estimates for the non-linear model for the same three industries.

Table 3 goes here. 
First, consider the probability of ownership change, $\operatorname{Pr}(A C)$. The estimated coefficients for the ownership change variable are significantly negative in all three industries over 1977-82. The interaction of plant size and acquisitions, $\operatorname{LnEMP}_{77} * \operatorname{Pr}(A C)$, reverses itself from $\operatorname{Pr}(A C)$ alone and is positive, suggesting that smaller plants were less likely to be closed than were very large ones. This finding is consistent with McGuckin and Nguyen (2001).

The results differ markedly for 1982-92. The estimated coefficients for $\operatorname{Pr}(A C)$ are positive in four cases, significantly so in three cases, and insignificant and negative in two cases. In contrast, the coefficients of the interaction term, $\operatorname{Pr}(A C){ }^{*} \operatorname{LnEM} P_{82}$, are significant and positive, implying that small plants were more likely to be closed than large ones over 1982-92.

\section{Table 4 goes here.}

The above results show that the merger waves of 1977-82 and 1982-87 were distinctly different and match anecdotal evidence. The meat packing and prepared meats industries underwent a major transformation in the earlier period (1977-82), as entrants and upstarts producing boxed meat products in huge plants replaced many well-established, large manufacturers that produced carcasses in large plants (MacDonald et al,1999; Ollinger, MacDonald, and Madison, 2000). As a result, many big factories came onto the merger market and many of these were outdated. At the same time, growth in per capita beef and pork consumption dropped, making production cutbacks necessary. The result was a huge consolidation with many large plants being shut down. By 1982, the large plants that remained 
were less likely to be shut down because they benefited from economies of scale and produced higher value boxed meat products.

Other results are consistent with previous studies. Similar to Dunne, Roberts, and Samuelson (1989), plant size negatively affected plant closures in all three industries. Plant age also consistently discouraged plant closures, possibly because more experienced management could more readily adapt to the changing economic environment. Results also show that a higher ratio of wages to costs led to a greater likelihood of plant closure in small plants but not large ones. Finally, plants owned by multi-plant firms were more likely to be closed.

\section{CONCLUDING REMARKS}

In this article, we examined the effect of plant acquisitions on plant employment, wages and plant closures during two merger waves 1977-82 and 1982-87. We found that M\&As positively affected employment at plants acquired during 1977-82, but not at those acquired during 1982-87 and had a significantly positive effect on wage growth over 1977-87 and a positive but insignificant effect over 1982-92. We also determined that M\&As increased the likelihood of survival of small plants acquired during 1977-82, and decreased the likelihood of closure of large plants acquired during 1982-87. Overall, these results do not support the view that M\&As caused worker dislocation and lost wages, but they also do not suggest that being part of an M\&A increased wages and employment. At best, workers in acquired plants had modest increases in job security and wages relative to their peers in plant that were not acquired. 


\section{REFERENCES}

Ashenfelter, O. and Kruger, A. B. (1994). Estimates of the Economic Return to Schooling from a New Sample of Twins, American Economic Review, 84, 1157-73.

Baldwin, J. (1991). The Dynamics of the Competitive Process, Unpublished manuscript, Queen's University.

Block, F. E. (1979). Evaluating Manpower Training Programs. Greenwich, Conn.: JAI Press.

Brown, C. and Medoff, J.L. (1988). The Impact of Firm Acquisition on Labor. In Corporate Takeovers: Causes and Consequences, Alan J. Auerbach (Ed.), 9-25. Chicago and London: The University of Chicago Press.

59. (1989). The Employer Size-Wage Effect, Journal of Political Economy, 97, 1027-

Caves, R.E. (1998). Industrial Organization and New Findings on the Turnover and Mobility of Firms, Journal of Economic Literature, 36, 1947-1982.

Dunne, T. and Roberts, M. (1993). The Long-Run Demand for Labor: Estimates from Census Establishment Data. CES Discussion Paper 93-13. Washington, D.C.: U.S. Bureau of the Census, Center for Economic Studies.

(1990). Wages and the Risk of Plant Closings. CES Discussion 90-6. Washington, D.C.: U.S. Bureau of the Census, Center for Economic Studies.

Dunne, T., Roberts, M., and Samuelson, L. (1989). The Growth and Failure of U.S. Manufacturing Plants, Quarterly Journal of Economics, 104, 671-98.

(1992). Corporate Takeovers and Productivity. Cambridge: The MIT Press.

Green, W.(2000). Econometric Analysis, $4^{\text {th }}$ edition, New Jersey: Prentice Hall.

Lichtenberg, F.R. and Siegel, D. (1992a). Productivity and Changes in Ownership of Manufacturing Plants. In Corporate Takeovers and Productivity, F. Lichtenberg (Ed.), 25-43. Cambridge, MA.: The MIT Press.

(1992b), Takeovers and Corporate Overhead. In Corporate Takeovers and Productivity, F. Lichtenberg (Ed.), 45-67. Cambridge, MA.: The MIT Press.

MacDonald, J. M., Ollinger, M., Nelson, K., and Handy C. (1999). Consolidation in U.S. Meat 
Packing. AER- 785. Washington, D.C.: U.S. Department of Agriculture, Economic Research Service.

McGuckin, R.H. and Nguyen, S.V. (1995), On Productivity and Plant Ownership Change: New Evidence from the LRD, The RAND Journal of Economics, 26, 257-76.

(1998). Exploring the Role of Acquisition in the Performance of Firms: Is the "Firm" the Right Unit of Analysis? In Micro and Macro-data Statistical Analysis and International Comparison, Sylvia Biffigandi (Ed.), 1-23. Italy: Physia-verlag.

(2001). The Impact of Ownership Change: A View from Labor Market.

International Journal of Industrial Organizations, 19, 739-762.

McGuckin, R.H., Nguyen, S.V., and Reznek, A.P. (1997). On Measuring the Impact of Ownership Change on Labor: Evidence from U.S. Food Manufacturing Data. In Labor Statistics Measurement Issue, John Haltiwanger, Marilyn Manser and Robert Topel (Eds.), NBER, Studies in Income and Wealth, 60. Chicago and London: University of Chicago Press.

McGuckin, R.H. and Pascoe, G. (1988). The Longitudinal Research Database: Status and Research Possibilities, Survey of Current Business, 68, 30-37.

Nguyen, S. V. (1998) The Manufacturing Plant Ownership Change Database: Its Construction and Usefulness. Journal of Economic and Social Measurement 24, 209-232.

Nguyen, S. V. and Ollinger, M. (2006), Mergers and Acquisitions and productivity in the U. S. Meat products Industries: Evidence from Micro-data. American Journal of Agricultural Economics, 88, 606-616.

Ollinger, M., MacDonald J., and Madison M. (2000). Structural Change in U.S. Chicken and Turkey Slaughter. Washington D.C.: U.S. Department of Agriculture: Economic Research Service.

Ollinger, M., Nguyen, S. V., Blayney D., Chambers B., and Nelson K. (2005). Structural Change in Meat, Dairy, and Grain Processing. ERR-3. Washington D.C.: U.S. Department of Agriculture: Economic Research Service, ERR-3. 
Table 1. The Results for the Employment Equation.

\begin{tabular}{|c|c|c|c|c|c|c|}
\hline Variable & $\begin{array}{l}\text { Meat } \\
\text { Packing }\end{array}$ & $\begin{array}{l}\text { Prepared } \\
\text { Meat } \\
\text { Products }\end{array}$ & $\begin{array}{l}\text { Poultry } \\
\text { Slaughter } \\
\text { and } \\
\text { Processing }\end{array}$ & $\begin{array}{l}\text { Meat } \\
\text { Packing }\end{array}$ & $\begin{array}{l}\text { Prepared } \\
\text { Meat } \\
\text { Products }\end{array}$ & $\begin{array}{l}\text { Poultry } \\
\text { Slaughter } \\
\text { and } \\
\text { Processing }\end{array}$ \\
\hline & \multicolumn{3}{|c|}{----------1977-87----------- } & \multicolumn{3}{|c|}{---------1982-92--------- } \\
\hline Intercept & $\begin{array}{l}0.700^{* * *} \\
(0.232)\end{array}$ & $\begin{array}{l}0.277 \\
(0.240)\end{array}$ & \begin{tabular}{|l|}
0.529 \\
$(0.326)$
\end{tabular} & $\begin{array}{l}-0.228 \\
(0.189)\end{array}$ & $\begin{array}{l}-0.067 \\
(0.158)\end{array}$ & $\begin{array}{l}0.732^{* *} \\
(0.333)\end{array}$ \\
\hline $\operatorname{LnWAGE}_{\mathrm{t}-1}$ & $\begin{array}{l}0.072 \\
(0.085)\end{array}$ & $\begin{array}{l}0.268^{* * *} \\
(0.092)\end{array}$ & $\begin{array}{l}-0.132^{* * *} \\
(0.130)\end{array}$ & $\begin{array}{l}0.168^{* *} \\
(0.071)\end{array}$ & $\begin{array}{l}0.186^{* * *} \\
(0.053)\end{array}$ & $\begin{array}{l}-0.124 \\
(0.091)\end{array}$ \\
\hline $\operatorname{LnEMP}_{\mathrm{t}-1}$ & $\begin{array}{l}-0.325^{* * *} \\
(0.087)\end{array}$ & $\begin{array}{l}-0.488^{* * * *} \\
(0.097)\end{array}$ & $\begin{array}{l}0.138 \\
(0.132) \\
\end{array}$ & $\begin{array}{l}-0.236^{* * * *} \\
(0.080)\end{array}$ & $\begin{array}{l}-0.266^{* * *} \\
(0.066)\end{array}$ & $\begin{array}{l}0.073 \\
(0.094) \\
\end{array}$ \\
\hline $\operatorname{Ln}(\Delta \mathrm{NPW} / \mathrm{PW})$ & $\begin{array}{l}0.065 \\
(0.042)\end{array}$ & $\begin{array}{l}0.075^{* *} \\
(0.033)\end{array}$ & $\begin{array}{l}-0.023 \\
(0.017)\end{array}$ & $\begin{array}{l}0.096^{* *} \\
(0.050)\end{array}$ & $\begin{array}{l}0.025 \\
(0.030)\end{array}$ & $\begin{array}{l}0.052 \\
(0.034)\end{array}$ \\
\hline $\operatorname{Ln}(\Delta \mathrm{K} / \mathrm{S})$ & $\begin{array}{l}-0.009^{* * *} \\
(0.002) \\
\end{array}$ & $\begin{array}{l}0.017 \\
(0.011)\end{array}$ & $\begin{array}{l}-0.009^{* * *} \\
(0.002)\end{array}$ & $\begin{array}{l}-0.0003 \\
(0.0007) \\
\end{array}$ & $\begin{array}{l}-0.0004 \\
(0.0005) \\
\end{array}$ & $\begin{array}{l}-0.0001 \\
(0.0004) \\
\end{array}$ \\
\hline $\mathrm{Ln}(\Delta \mathrm{SP}$ RATIO $)$ & $\begin{array}{l}-0.007 \\
(0.013)\end{array}$ & $\begin{array}{l}0.018^{* *} \\
(0.008)\end{array}$ & $\begin{array}{l}-0.125^{* *} \\
(0.065)\end{array}$ & $\begin{array}{l}0.025 \\
(0.056)\end{array}$ & $\begin{array}{l}0.017 \\
(0.051)\end{array}$ & $\begin{array}{l}0.133^{*} \\
(0.075)\end{array}$ \\
\hline $\operatorname{Pr}(\mathrm{AC})$ & $\begin{array}{l}1.232^{* * *} \\
(0.211)\end{array}$ & $\begin{array}{l}1.200^{* * *} \\
(0.435)\end{array}$ & $\begin{array}{l}0.568^{* *} \\
(0.273)\end{array}$ & $\begin{array}{l}-0.062 \\
(0.368)\end{array}$ & $\begin{array}{l}-0.226 \\
(0.374)\end{array}$ & $\begin{array}{l}1.217^{* *} \\
(0.565)\end{array}$ \\
\hline BUYER_PLANT & $\begin{array}{l}0.102 \\
(0.082)\end{array}$ & $\begin{array}{l}-0.107 \\
(0.099) \\
\end{array}$ & $\begin{array}{l}0.021 \\
(0.064)\end{array}$ & $\begin{array}{l}0.015 \\
(0.073)\end{array}$ & $\begin{array}{l}-0.180^{* * *} \\
(0.056)\end{array}$ & $\begin{array}{l}-0.079 \\
(0.058)\end{array}$ \\
\hline AGE72 & $\begin{array}{l}-0.094 \\
(0.061)\end{array}$ & $\begin{array}{l}-0.211^{* * *} \\
(0.068)\end{array}$ & $\begin{array}{l}-0.257^{* * *} \\
(0.081)\end{array}$ & $\begin{array}{l}-0.195 \\
(0.070)\end{array}$ & $\begin{array}{l}-0.225^{* * *} \\
(0.059)\end{array}$ & $\begin{array}{l}-0.272^{* * *} \\
(0.087)\end{array}$ \\
\hline AGE77 & - & - & - & $\begin{array}{l}-0.055 \\
(0.084) \\
\end{array}$ & $\begin{array}{l}-0.062 \\
(0.069) \\
\end{array}$ & $\begin{array}{l}-0.059 \\
(0.095) \\
\end{array}$ \\
\hline MULTI & $\begin{array}{l}0.126 \\
(0.336)\end{array}$ & $\begin{array}{l}0.682^{* *} \\
(0.298)\end{array}$ & $\begin{array}{l}-0.741 \\
(0.520)\end{array}$ & $\begin{array}{l}0.332 \\
(0.372)\end{array}$ & $\begin{array}{l}0.304 \\
(0.251)\end{array}$ & $\begin{array}{l}-0.611 \\
(0.498)\end{array}$ \\
\hline OT_MEAT & $\begin{array}{l}-1.017^{* * *} \\
(0.221)^{* * *}\end{array}$ & $\begin{array}{l}-0.744^{* * *} \\
(0.283) \\
\end{array}$ & $\begin{array}{l}0.115 \\
(0.244) \\
\end{array}$ & $\begin{array}{l}0.153 \\
(0.212) \\
\end{array}$ & $\begin{array}{l}0.035 \\
(0.165) \\
\end{array}$ & $\begin{array}{l}0.268 \\
(0.220) \\
\end{array}$ \\
\hline NOT_FOOD & $\begin{array}{l}-1.468^{* * * *} \\
(0.329)\end{array}$ & $\begin{array}{l}-1.123 \\
(0.716)\end{array}$ & $\begin{array}{l}0.572 \\
(0.458)\end{array}$ & $\begin{array}{l}0.247 \\
(0.444)\end{array}$ & $\begin{array}{l}0.268 \\
(0.345)\end{array}$ & $\begin{array}{l}-0.171 \\
(0.517)\end{array}$ \\
\hline MULT*LnEMP $_{\mathrm{t}-1}$ & $\begin{array}{l}0.021 \\
(0.062)\end{array}$ & $\begin{array}{l}-0.137^{* *} \\
(0.063)\end{array}$ & $\begin{array}{l}0.143 \\
(0.092)\end{array}$ & $\begin{array}{l}0.008 \\
(0.067)\end{array}$ & $\begin{array}{l}0.005 \\
(0.046)\end{array}$ & $\begin{array}{l}0.129 \\
(0.082)\end{array}$ \\
\hline $\begin{array}{l}\text { OT_MEAT* }^{*} \\
\text { LnEMP }_{t-1}\end{array}$ & $\begin{array}{l}0.221^{* * *} \\
(0.047)\end{array}$ & $\begin{array}{l}0.150^{* * *} \\
(0.051)\end{array}$ & $\begin{array}{l}-0.083^{*} \\
(0.051)\end{array}$ & $\begin{array}{l}-0.005 \\
(0.045)\end{array}$ & $\begin{array}{l}0.038 \\
(0.034)\end{array}$ & $\begin{array}{l}-0.160^{*} \\
(0.047)\end{array}$ \\
\hline $\begin{array}{l}\text { NOT_FOOD* } \\
\text { LnEMP }_{t-1}\end{array}$ & $\begin{array}{l}0.275^{* * *} \\
(0.593)\end{array}$ & $\begin{array}{l}0.182 \\
(0.133)\end{array}$ & $\begin{array}{l}-0.194^{* *} \\
(0.093)\end{array}$ & $\begin{array}{l}-0.017 \\
(0.075)\end{array}$ & $\begin{array}{l}0.003 \\
(0.062)\end{array}$ & $\begin{array}{l}-0.028 \\
(0.096)\end{array}$ \\
\hline $\mathrm{R}^{2}$ & .156 & .149 & .113 & .040 & .059 & .125 \\
\hline OBS & 916 & 654 & 553 & 850 & 1033 & 605 \\
\hline
\end{tabular}

Notes: Standard errors are in parentheses. Dependent Variable is $\operatorname{Ln}\left(E m p_{t}\right)-\operatorname{Ln}\left(E m p_{t-1}\right){ }^{*}$, **, * denote significance at 10,5 , and 1 percent significance levels. 
Table 2. The Results for the Wage Equation.

\begin{tabular}{|c|c|c|c|c|c|c|}
\hline Variable & $\begin{array}{l}\text { Meat } \\
\text { Packing }\end{array}$ & $\begin{array}{l}\text { Prepared } \\
\text { Meat } \\
\text { Products }\end{array}$ & $\begin{array}{l}\text { Poultry } \\
\text { Slaughter } \\
\text { and } \\
\text { Processing }\end{array}$ & $\begin{array}{l}\text { Meat } \\
\text { Packing }\end{array}$ & $\begin{array}{l}\text { Prepared } \\
\text { Meat } \\
\text { Products }\end{array}$ & $\begin{array}{l}\text { Poultry } \\
\text { Slaughter } \\
\text { and } \\
\text { Processing }\end{array}$ \\
\hline & \multicolumn{3}{|c|}{ | } & \multicolumn{3}{|c|}{-------1982-92------י } \\
\hline Intercept & $\begin{array}{l}1.544^{* * *} \\
(0.252)\end{array}$ & \begin{tabular}{|l}
$1.206^{* * *}$ \\
$(0.264)$
\end{tabular} & $\begin{array}{l}1.556^{* * *} \\
(0.332)\end{array}$ & $\begin{array}{l}0.278 \\
(0.080)\end{array}$ & $\begin{array}{l}0.358^{* * * *} \\
(0.083)\end{array}$ & $\begin{array}{l}0.402^{* * *} \\
(0.142)\end{array}$ \\
\hline LnWAGE $_{\mathrm{t}-1}$ & $\begin{array}{l}-0.409^{* * * *} \\
(0.093)\end{array}$ & $\begin{array}{l}-0.199^{* *} \\
(0.102)\end{array}$ & $\begin{array}{l}-0.498^{* * * *} \\
(0.133)\end{array}$ & $\begin{array}{l}-0.064^{* *} \\
(0.030)\end{array}$ & $\begin{array}{l}0.058^{* *} \\
(0.028)\end{array}$ & $\begin{array}{l}-0.093^{* *} \\
(0.039)\end{array}$ \\
\hline $\operatorname{LnEMP}_{\mathrm{t}-1}$ & $\begin{array}{l}0.337^{* * *} \\
(0.095)\end{array}$ & $\begin{array}{l}0.162 \\
(0.107)\end{array}$ & $\begin{array}{l}0.558^{* * *} \\
(0.134)\end{array}$ & $\begin{array}{c}0.043 \\
(0.033)\end{array}$ & $\begin{array}{l}0.039 \\
(0.034)\end{array}$ & $\begin{array}{l}0.073^{*} \\
(0.042)\end{array}$ \\
\hline $\operatorname{Ln}(\Delta \mathrm{NPWW} / \mathrm{PWW})$ & $\begin{array}{l}0.081^{*} \\
(0.046)\end{array}$ & $\begin{array}{l}0.079^{* *} \\
(0.037)\end{array}$ & $\begin{array}{l}0.004 \\
(0.018)\end{array}$ & $\begin{array}{l}0.272^{* * * *} \\
(0.021)\end{array}$ & $\begin{array}{l}0.168^{* * *} \\
(0.016)\end{array}$ & $\begin{array}{l}0.125^{* * *} \\
(0.014)\end{array}$ \\
\hline $\operatorname{Ln}(\Delta \mathrm{K} / \mathrm{S})$ & $\begin{array}{l}-0.009^{* * * 1} \\
(0.002)\end{array}$ & $\begin{array}{l}0.019 \\
(0.012)\end{array}$ & $\begin{array}{l}-0.009^{* * * 1} \\
(0.002)\end{array}$ & $\begin{array}{l}0.0005^{*} \\
(0.0003)\end{array}$ & $\begin{array}{l}0.0002 \\
(0.0003)\end{array}$ & $\begin{array}{l}-0.0001 \\
(0.0002)\end{array}$ \\
\hline Ln( $\triangle$ SP_RATIO $)$ & $\begin{array}{l}-0.010 \\
(0.015)\end{array}$ & $\begin{array}{l}0.021^{* *} \\
(0.008)\end{array}$ & $\begin{array}{l}-0.152^{* *} \\
(0.066)\end{array}$ & $\begin{array}{l}0.035 \\
(0.024)\end{array}$ & $\begin{array}{l}0.032 \\
(0.027)\end{array}$ & $\begin{array}{l}0.042 \\
(0.031)\end{array}$ \\
\hline $\operatorname{Pr}(\mathrm{AC})$ & $\begin{array}{l}0.835^{* * * *} \\
(0.230)\end{array}$ & $\begin{array}{l}1.088^{* *} \\
(0.480)\end{array}$ & $\begin{array}{l}0.443 \\
(0.278)\end{array}$ & $\begin{array}{c}0.128 \\
(0.155)\end{array}$ & $\begin{array}{l}0.032 \\
(0.196)\end{array}$ & $\begin{array}{l}0.187 \\
(0.216)\end{array}$ \\
\hline BUYER_PLANT & $\begin{array}{l}0.168^{*} \\
(0.090)\end{array}$ & $\begin{array}{l}-0.150 \\
(0.109)\end{array}$ & $\begin{array}{l}0.042 \\
(0.065)\end{array}$ & $\begin{array}{l}0.027 \\
(0.031)\end{array}$ & $\begin{array}{l}0.002 \\
(0.029)\end{array}$ & $\begin{array}{l}0.037 \\
(0.025)\end{array}$ \\
\hline AGE72 & $\begin{array}{l}-0.112^{*} \\
(0.066)\end{array}$ & $\begin{array}{l}-0.215^{* *} \\
(0.075)\end{array}$ & $\begin{array}{l}-0.195^{* *} \\
(0.083)\end{array}$ & $\begin{array}{l}-0.042 \\
(0.029)\end{array}$ & $\begin{array}{l}-0.026 \\
(0.031)\end{array}$ & $\begin{array}{l}-0.011 \\
(0.036)\end{array}$ \\
\hline AGE77 & - & - & - & $\begin{array}{c}0.030 \\
(0.035)\end{array}$ & $\begin{array}{l}0.010 \\
(0.035)\end{array}$ & $\begin{array}{l}0.038 \\
(0.041)\end{array}$ \\
\hline MULTI & $\begin{array}{l}0.655^{*} \\
(0.364)\end{array}$ & $\begin{array}{l}1.104^{* * * *} \\
(0.328)\end{array}$ & $\begin{array}{l}-0.095 \\
(0.529)\end{array}$ & $\begin{array}{l}0.142 \\
(0.156)\end{array}$ & $\begin{array}{l}0.298^{* *} \\
(0.131)\end{array}$ & $\begin{array}{l}-0.073 \\
(0.214)\end{array}$ \\
\hline OT_MEAT & $\begin{array}{l}-0.163 \\
(0.240)\end{array}$ & $\begin{array}{l}-0.078 \\
(0.312)\end{array}$ & $\begin{array}{l}0.477^{* *} \\
(0.248)\end{array}$ & $\begin{array}{l}-0.00002 \\
(0.089)\end{array}$ & $\begin{array}{l}-0.043 \\
(0.086)\end{array}$ & $\begin{array}{l}-0.060 \\
(0.066)\end{array}$ \\
\hline NOT_FOOD & $\begin{array}{l}-0.268 \\
(0.357)\end{array}$ & $\begin{array}{l}-0.929 \\
(0.790)\end{array}$ & $\begin{array}{l}0.598 \\
(0.450)\end{array}$ & $\begin{array}{l}0.114 \\
(0.187)\end{array}$ & $\begin{array}{l}0.197 \\
(0.170)\end{array}$ & $\begin{array}{l}-0.349^{* *} \\
(0.175)\end{array}$ \\
\hline MULTI*LnEMP $_{\mathrm{t}-1}$ & $\begin{array}{l}-0.091 \\
(0.357)\end{array}$ & $\begin{array}{l}-0.242^{* * * *} \\
(0.069)\end{array}$ & $\begin{array}{l}0.018 \\
(0.093)\end{array}$ & $\begin{array}{l}-0.023 \\
(0.028)\end{array}$ & $\begin{array}{l}-0.054^{* *} \\
(0.024)\end{array}$ & $\begin{array}{l}0.006 \\
(0.036)\end{array}$ \\
\hline $\begin{array}{l}\text { OT_MEAT* }^{*} \\
\text { LnEMP }_{t-1}\end{array}$ & $\begin{array}{l}0.065 \\
(0.051)\end{array}$ & $\begin{array}{l}0.015 \\
(0.057)\end{array}$ & $\begin{array}{l}-0.105^{* *} \\
(0.052)\end{array}$ & $\begin{array}{l}0.003 \\
(0.019)\end{array}$ & $\begin{array}{l}0.006 \\
(0.018)\end{array}$ & $\begin{array}{l}-0.002 \\
(0.010)\end{array}$ \\
\hline $\begin{array}{l}\text { NOT_FOOD* }^{*} \\
\text { LnEMP }_{t-1}\end{array}$ & $\begin{array}{l}0.082 \\
(0.064)\end{array}$ & $\begin{array}{l}0.153 \\
(0.147)\end{array}$ & $\begin{array}{l}-0.124 \\
(0.097)\end{array}$ & $\begin{array}{l}-0.008 \\
(0.031)\end{array}$ & $\begin{array}{l}-0.035 \\
(0.035)\end{array}$ & $\begin{array}{l}-0.061 \\
(0.043)\end{array}$ \\
\hline $\mathrm{R}^{2}$ & .085 & .056 & .113 & .179 & .118 & .145 \\
\hline OBS & 916 & 654 & 553 & 850 & 1033 & 605 \\
\hline
\end{tabular}

Notes: Standard errors are in parentheses. Dependent Variable is Ln $\left(\right.$ Wage $\left._{t}\right)-\operatorname{Ln}\left(\right.$ Wage $\left._{t-1}\right)$. $*, * *, *$ denote significance at 10,5 , and 1 percent significance levels. 
Table 3. Probit Regression Results of Plant Closures (Plants acquired in 1977-82).

\begin{tabular}{|c|c|c|c|c|c|c|}
\hline \multirow[t]{2}{*}{$\begin{array}{l}\text { Dependent } \\
\text { Variable }\end{array}$} & \multicolumn{2}{|c|}{ Meat Packing } & \multicolumn{2}{|c|}{$\begin{array}{l}\text { Prepared Meat } \\
\text { Products }\end{array}$} & \multicolumn{2}{|c|}{$\begin{array}{l}\text { Poultry Slaughter and } \\
\text { Processing }\end{array}$} \\
\hline & (1) & (2) & (3) & (4) & (5) & (6) \\
\hline Intercept & $\begin{array}{l}1.288^{* * *} \\
(0.058)\end{array}$ & $\begin{array}{l}2.007^{* * *} \\
(0.175)\end{array}$ & $\begin{array}{l}0.259^{* * * *} \\
(0.081)\end{array}$ & $\begin{array}{l}1.600^{* * * *} \\
(0.234)\end{array}$ & $\begin{array}{l}1.025^{* * *} \\
(0.091)\end{array}$ & $\begin{array}{l}4.249^{* * *} \\
(0.278)\end{array}$ \\
\hline LnPROD77 & $\begin{array}{l}0.149 \\
(0.019)\end{array}$ & $\begin{array}{l}0.473^{* * *} \\
(0.058)\end{array}$ & $\begin{array}{l}-0.141^{*{ }^{* * *}} \\
(0.029)\end{array}$ & $\begin{array}{l}0.222^{* *} \\
(0.097)\end{array}$ & $\begin{array}{l}1.139^{* * *} \\
(0.033)\end{array}$ & $\begin{array}{l}1.013^{* * *} \\
(0.119)\end{array}$ \\
\hline LnEMP $_{77}$ & $\begin{array}{l}-0.306^{* * * *} \\
(0.008)\end{array}$ & $\begin{array}{l}-0.480^{* * *} \\
(0.043)\end{array}$ & $\begin{array}{l}-0.336^{* * *} \\
(0.011)\end{array}$ & $\begin{array}{l}-0.668^{* * *} \\
(0.056)\end{array}$ & $\begin{array}{l}-0.323^{* *} \\
(0.015)\end{array}$ & $\begin{array}{l}-1.098^{* *} \\
(0.064)\end{array}$ \\
\hline LnWAG_SHARE & $\begin{array}{l}0.216^{* * *} \\
(0.020)\end{array}$ & $\begin{array}{l}0.478^{* * * *} \\
(0.067)\end{array}$ & $\begin{array}{l}-0.011 \\
(0.034)\end{array}$ & $\begin{array}{l}0.687^{* * * *} \\
(0.111)\end{array}$ & $\begin{array}{l}0.152^{* * *} \\
(0.029)\end{array}$ & $\begin{array}{l}1.595^{* * *} \\
(0.129)\end{array}$ \\
\hline $\operatorname{Pr}(\mathrm{AC})$ & $\begin{array}{l}-1.438^{* * *} \\
(0.152)\end{array}$ & $\begin{array}{l}-2.372^{* * *} \\
(0.760)\end{array}$ & $\begin{array}{l}-1.040^{* * *} \\
(0.145)\end{array}$ & $\begin{array}{l}-3.847^{* * * 7} \\
(0.574)\end{array}$ & $\begin{array}{l}-1.939^{* *} \\
(0.175)\end{array}$ & $\begin{array}{l}-6.486^{* * *} \\
(0.689)\end{array}$ \\
\hline BUYER_PLANT & $\begin{array}{l}0.394^{* * * *} \\
(0.039)\end{array}$ & $\begin{array}{l}1.243^{* * *} \\
(0.146)\end{array}$ & $\begin{array}{l}0.432^{* * * *} \\
(0.047)\end{array}$ & $\begin{array}{l}0.766^{* * * *} \\
(0.164)\end{array}$ & $\begin{array}{l}0.043 \\
(0.041)\end{array}$ & $\begin{array}{l}0.615^{* * *} \\
(0.141)\end{array}$ \\
\hline AGE72 & $\begin{array}{l}-0.095^{* * *} \\
(0.020)\end{array}$ & $\begin{array}{l}-0.103^{* * * 7} \\
(0.021)\end{array}$ & $\begin{array}{l}-0.083^{* * * *} \\
(0.029)\end{array}$ & $\begin{array}{l}-0.097^{* * * 7} \\
(0.029)\end{array}$ & $\begin{array}{l}-0.137^{* *} \\
(0.038)\end{array}$ & $\begin{array}{l}-0.137^{* * *} \\
(0.039)\end{array}$ \\
\hline MULTI & $\begin{array}{l}0.544^{* * * *} \\
(0.038)\end{array}$ & $\begin{array}{l}0.427^{* * *} \\
(0.134)\end{array}$ & $\begin{array}{l}0.554^{* * * *} \\
(0.041)\end{array}$ & $\begin{array}{l}0.338^{* *} \\
(0.140)\end{array}$ & $\begin{array}{l}0.400^{* * *} \\
(0.049)\end{array}$ & $\begin{array}{l}0.635^{* * *} \\
(0.182) \\
\end{array}$ \\
\hline OT_MEAT & $\begin{array}{l}-0.455^{* * *} \\
(0.040)\end{array}$ & $\begin{array}{l}-1.097^{* * * 7} \\
(0.157)\end{array}$ & $\begin{array}{l}-0.300^{* * *} \\
(0.045)\end{array}$ & $\begin{array}{l}-0.278^{* * *} \\
(0.031)\end{array}$ & $\begin{array}{l}-0.045 \\
(0.049)\end{array}$ & $\begin{array}{l}0.072 \\
(0.147)\end{array}$ \\
\hline NOT_FOOD & $\begin{array}{l}0.373^{* * *} \\
(0.039)\end{array}$ & $\begin{array}{l}0.003 \\
(0.793)\end{array}$ & $\begin{array}{l}0.069 \\
(0.052)\end{array}$ & $\begin{array}{l}-1.137 \\
(0.207)\end{array}$ & $\begin{array}{l}0.293^{* * *} \\
(0.058)\end{array}$ & $\begin{array}{l}-1.025^{* * * *} \\
(0.199)\end{array}$ \\
\hline $\begin{array}{l}\text { LnPROD77* }^{*} \\
\text { LnEMP }_{77}\end{array}$ & - & $\begin{array}{l}-0.090^{* * *} \\
(0.015)\end{array}$ & - & $\begin{array}{l}-0.092^{* * *} \\
(0.024)\end{array}$ & - & $\begin{array}{l}-0.275^{* * *} \\
(0.029)\end{array}$ \\
\hline $\begin{array}{l}\text { LnWAG_SHARE* } \\
\text { LnEMP }_{77}\end{array}$ & - & $\begin{array}{l}-0.064^{* * *} \\
(0.016)\end{array}$ & - & $\begin{array}{l}-0.183^{* * *} \\
(0.027) \\
\end{array}$ & - & $\begin{array}{l}-0.362^{* * *} \\
(0.032)\end{array}$ \\
\hline $\operatorname{Pr}(\mathrm{AC}) * \operatorname{LnEMP}_{77}$ & - & $\begin{array}{l}0.173 \\
(0.117)\end{array}$ & - & $\begin{array}{l}0.557^{* * *} \\
(0.106)\end{array}$ & - & $\begin{array}{l}0.707^{* * *} \\
(0.112)\end{array}$ \\
\hline $\begin{array}{l}\text { BUYER_PLANT* } \\
\text { LnEMP }_{77}\end{array}$ & - & $\begin{array}{l}-0.192^{* * * *} \\
(0.032)\end{array}$ & - & $\begin{array}{l}-0.060 \\
(0.038)\end{array}$ & - & $\begin{array}{l}-0.116^{* * *} \\
(0.031)\end{array}$ \\
\hline MULTI*LnEMP $_{77}$ & - & $\begin{array}{l}0.022 \\
(0.031)\end{array}$ & - & $\begin{array}{l}0.033 \\
(0.033) \\
\end{array}$ & - & $\begin{array}{l}-0.039 \\
(0.039)\end{array}$ \\
\hline $\begin{array}{l}\text { OT_MEAT* }^{*} \\
\text { LnEMP }_{77}\end{array}$ & - & $\begin{array}{l}0.157^{* * * *} \\
(0.034)\end{array}$ & - & $\begin{array}{l}-0.277^{* * * *} \\
(0.031)\end{array}$ & - & $\begin{array}{l}-0.046 \\
(0.032)\end{array}$ \\
\hline $\begin{array}{l}\text { NOT_FOOD* } \\
\text { LnEMP }_{77}\end{array}$ & - & $\begin{array}{l}0.150 \\
(0.130)\end{array}$ & - & $\begin{array}{l}0.356 \\
(0.047)\end{array}$ & - & $\begin{array}{l}0.304^{* * *} \\
(0.046)\end{array}$ \\
\hline Log likelihood & -12854 & -12779 & -6889 & -6798 & -3865 & -3768 \\
\hline OBS & 3066 & 3066 & 1803 & 1803 & 1276 & 1276 \\
\hline
\end{tabular}

Notes: Standard errors are in parentheses. Dependent Variable is Plant Closure $(\mathrm{PC}=1,0)$.

$*, * *, *$ denote significance at 10,5 , and 1 percent significance levels. 
Table 4 Probit Regression Results of Plant Closures (Plants acquired in 1982-87).

\begin{tabular}{|c|c|c|c|c|c|c|}
\hline \multirow[t]{2}{*}{$\begin{array}{l}\text { Dependent } \\
\text { Variables }\end{array}$} & \multicolumn{2}{|c|}{ Meat Packing } & \multicolumn{2}{|c|}{ Prepared Meat Products } & \multicolumn{2}{|c|}{$\begin{array}{l}\text { Poultry Slaughter and } \\
\text { Processing }\end{array}$} \\
\hline & (1) & $(2)$ & (3) & (4) & (5) & (6) \\
\hline Intercept & $\begin{array}{l}0.614^{* * *} \\
(0.078)\end{array}$ & $\begin{array}{l}-0.160 \\
(0.158)\end{array}$ & $\begin{array}{l}0.515^{* * *} \\
(0.064)\end{array}$ & $\begin{array}{l}0.593^{* * *} \\
(0.161) \\
\end{array}$ & $\begin{array}{l}1.152^{* * *} \\
(0.082)\end{array}$ & $\begin{array}{l}0.403^{*} \\
(0.228)\end{array}$ \\
\hline LnPROD82 & $\begin{array}{l}0.106^{* * *} \\
(0.019)\end{array}$ & $\begin{array}{l}-0.089^{* *} \\
(0.038)\end{array}$ & $\begin{array}{l}-0.039^{* *} \\
(0.019)\end{array}$ & $\begin{array}{l}-0.012 \\
(0.046)\end{array}$ & $\begin{array}{l}0.185^{* * *} \\
(0.032)\end{array}$ & $\begin{array}{l}0.053 \\
(0.098)\end{array}$ \\
\hline $\operatorname{LnEMP}_{82}$ & $\begin{array}{l}-0.168^{* * * *} \\
(0.009)\end{array}$ & $\begin{array}{l}0.122^{* *} \\
(0.049)\end{array}$ & $\begin{array}{l}-0.326^{* *} \\
(0.013)\end{array}$ & $\begin{array}{l}-0.371^{* * *} \\
(0.042)\end{array}$ & $\begin{array}{l}-0.286^{* *} \\
(0.017)\end{array}$ & $\begin{array}{l}0.019 \\
(0.073)\end{array}$ \\
\hline LnWAGE_SHARE & $\begin{array}{l}0.177^{* * *} \\
(0.024)\end{array}$ & $\begin{array}{l}-0.041 \\
(0.054)\end{array}$ & $\begin{array}{c}0.147^{* * *} \\
(0.023)\end{array}$ & $\begin{array}{l}-0.266^{* * *} \\
(0.069)\end{array}$ & $\begin{array}{l}0.342^{* * *} \\
(0.030)\end{array}$ & $\begin{array}{l}0.042 \\
(0.096)\end{array}$ \\
\hline $\operatorname{Pr}(\mathrm{AC})$ & $\begin{array}{l}-0.047 \\
(0.161)\end{array}$ & $\begin{array}{l}0.424 \\
(0.571) \\
\end{array}$ & $\begin{array}{l}1.626^{* *} \\
(0.189)\end{array}$ & $\begin{array}{l}5.847^{* * * *} \\
(0.676)\end{array}$ & $\begin{array}{l}-0.131 \\
(0.265)\end{array}$ & $\begin{array}{l}2.219^{* * *} \\
(1.077) \\
\end{array}$ \\
\hline BUYER_PLANT & $\begin{array}{l}0.099^{* *} \\
(0.038)\end{array}$ & $\begin{array}{l}0.222 \\
(0.141)\end{array}$ & $\begin{array}{l}0.217^{* * *} \\
(0.032)\end{array}$ & $\begin{array}{l}0.115 \\
(0.125) \\
\end{array}$ & $\begin{array}{l}0.349^{* * * *} \\
(0.034)\end{array}$ & $\begin{array}{l}-0.076 \\
(0.127) \\
\end{array}$ \\
\hline AGE72 & $\begin{array}{l}-0.083^{* * *} \\
(0.027)\end{array}$ & $\begin{array}{l}-0.098^{* * *} \\
(0.027)\end{array}$ & $\begin{array}{l}-0.029 \\
(0.029)\end{array}$ & $\begin{array}{l}-0.017 \\
(0.030)\end{array}$ & $\begin{array}{l}-0.130^{* *} \\
(0.039)\end{array}$ & $\begin{array}{l}-0.100^{* *} \\
(0.043)\end{array}$ \\
\hline AGE77 & $\begin{array}{l}-0.100^{* * *} \\
(0.031)\end{array}$ & $\begin{array}{l}-0.108^{* * *} \\
(0.032)\end{array}$ & $\begin{array}{l}-0.035 \\
(0.035) \\
\end{array}$ & $\begin{array}{l}-0.070^{* *} \\
(0.035)\end{array}$ & $\begin{array}{l}-0.041 \\
(0.771) \\
\end{array}$ & $\begin{array}{l}-0.054 \\
(0.048)\end{array}$ \\
\hline MULTI & $\begin{array}{l}-0.152^{* * *} \\
(0.040)\end{array}$ & $\begin{array}{l}0.377^{* *} \\
(0.152)\end{array}$ & $\begin{array}{l}0.126^{\text {w*** }} \\
(0.035)\end{array}$ & $\begin{array}{l}0.771^{* * * *} \\
(0.134)\end{array}$ & $\begin{array}{l}-0.065 \\
(0.059)\end{array}$ & $\begin{array}{l}0.547^{*} \\
(0.336)\end{array}$ \\
\hline OT_MEAT & $\begin{array}{l}-0.445^{* * *} \\
(0.056)\end{array}$ & $\begin{array}{l}0.159 \\
(0.173)\end{array}$ & $\begin{array}{l}-0.364 \\
(0.047)\end{array}$ & $\begin{array}{l}-0.756^{* * *} \\
(0.179)\end{array}$ & $\begin{array}{l}-0.119 \\
(0.075)\end{array}$ & $\begin{array}{l}-1.579^{* * *} \\
(0.202)\end{array}$ \\
\hline NOT_FOOD & $\begin{array}{l}1.128^{* * *} \\
(0.053)\end{array}$ & $\begin{array}{l}0.597^{* *} \\
(0.295)\end{array}$ & $\begin{array}{l}-0.253^{* *} \\
(0.039) \\
\end{array}$ & $\begin{array}{ll}0.058 \\
(0.152) \\
\end{array}$ & $\begin{array}{l}0.001 \\
(0.049) \\
\end{array}$ & $\begin{array}{l}1.457^{* * * *} \\
(0.206) \\
\end{array}$ \\
\hline $\begin{array}{l}\text { LnPROD82* }^{\text {LnPMP }} \\
\text { LnE2 }^{2}\end{array}$ & - & $\begin{array}{l}0.072^{* *} \\
(0.013)\end{array}$ & - & $\begin{array}{l}-0.017 \\
(0.013)\end{array}$ & - & $\begin{array}{l}0.053^{* *} \\
(0.024)\end{array}$ \\
\hline $\begin{array}{l}\text { LnWAGE_SHARE } \\
{ }^{*} \text { LnEMP }_{82}\end{array}$ & - & $\begin{array}{l}0.082^{* * *} \\
(0.016)\end{array}$ & - & $\begin{array}{l}-0.041^{* *} \\
(0.017)\end{array}$ & - & $\begin{array}{l}0.104^{* * * *} \\
(0.027)\end{array}$ \\
\hline $\begin{array}{l}\operatorname{Pr}(\mathrm{AC})^{*} \\
\mathrm{EMP}_{82}\end{array}$ & - & $\begin{array}{l}-0.206^{* *} \\
(0.088)\end{array}$ & - & $\begin{array}{l}-0.677^{* * *} \\
(0.116)\end{array}$ & - & $\begin{array}{l}-1.014^{* * * *} \\
(0.135)\end{array}$ \\
\hline $\begin{array}{l}\text { BUYKEEP* }^{*} \\
\text { LnEMP }_{82}\end{array}$ & - & $\begin{array}{l}-0.024 \\
(0.029)\end{array}$ & - & $\begin{array}{l}0.025 \\
(0.027)\end{array}$ & - & $\begin{array}{l}0.098^{* * * *} \\
(0.027)\end{array}$ \\
\hline $\begin{array}{l}\text { MULTI* }^{*} \\
\text { LnEMP }_{82}\end{array}$ & - & $\begin{array}{l}-0.107^{* * * *} \\
(0.031)\end{array}$ & - & $\begin{array}{l}-0.160^{* * * *} \\
(0.029)\end{array}$ & - & $\begin{array}{l}-0.040 \\
(0.055)\end{array}$ \\
\hline $\begin{array}{l}\text { OT_MEAT* } \\
\text { LnEMP }_{82}\end{array}$ & - & $\begin{array}{l}-0.073^{* *} \\
(0.036)\end{array}$ & - & $\begin{array}{l}0.028 \\
(0.035)\end{array}$ & - & $\begin{array}{l}0.456^{* * *} \\
(0.047)\end{array}$ \\
\hline $\begin{array}{l}\text { NOT_FOOD* } \\
\text { LnEMP }_{82}\end{array}$ & - & $\begin{array}{l}-0.198^{* * *} \\
(0.066)\end{array}$ & - & $\begin{array}{l}0.030 \\
(0.034)\end{array}$ & - & $\begin{array}{l}-0.409^{* * * *} \\
(0.059)\end{array}$ \\
\hline Log Likelihood & -9239 & -9188 & -8819 & -8718 & -4973 & -4867 \\
\hline OBS & 2090 & 2090 & 2108 & 2108 & 1169 & 1169 \\
\hline
\end{tabular}

Notes: Standard errors are in parentheses. Dependent Variable is Plant Closure $(\mathrm{PC}=1,0) .{ }^{*}, * *$, * denote significance at 10,5 , and 1 percent significance levels. 